University of Wollongong

Research Online

Faculty of Engineering and Information

Faculty of Engineering and Information

Sciences - Papers: Part A

Sciences

$1-1-2013$

\title{
Removal of bisphenol A and diclofenac by a novel fungal membrane bioreactor operated under non-sterile conditions
}

\author{
Shufan Yang \\ University of Wollongong, sy527@uowmail.edu.au \\ Faisal I. Hai \\ University of Wollongong, faisal@uow.edu.au \\ Long D. Nghiem \\ University of Wollongong, longn@uow.edu.au \\ Luong N. Nguyen \\ University of Wollongong, Inn909@uowmail.edu.au \\ Felicity Roddick \\ Royal Melbourne Institute Of Technology
}

See next page for additional authors

Follow this and additional works at: https://ro.uow.edu.au/eispapers

Part of the Engineering Commons, and the Science and Technology Studies Commons

Research Online is the open access institutional repository for the University of Wollongong. For further information contact the UOW Library: research-pubs@uow.edu.au 


\title{
Removal of bisphenol A and diclofenac by a novel fungal membrane bioreactor operated under non-sterile conditions
}

\author{
Abstract \\ Previous studies have confirmed significant removal of various trace organic contaminants (TrOCs) by \\ white-rot fungal cultures under sterile batch test conditions. However, little is known about TrOC removal \\ in continuous flow fungal reactors in a non-sterile environment. This study reports the removal of two \\ TrOCs, namely, bisphenol A and diclofenac, by a fungal membrane bioreactor (MBR).

\section{Keywords} \\ bisphenol, removal, non, under, operated, bioreactor, membrane, conditions, fungal, sterile, novel, \\ diclofenac \\ Disciplines \\ Engineering | Science and Technology Studies

\section{Publication Details} \\ Yang, S., Hai, F. I., Nghiem, L. D., Nguyen, L. N., Roddick, F. \& Price, W. E. (2013). Removal of bisphenol A \\ and diclofenac by a novel fungal membrane bioreactor operated under non-sterile conditions. \\ International Biodeterioration \& Biodegradation, 85 (November), 483-490.

\section{Authors} \\ Shufan Yang, Faisal I. Hai, Long D. Nghiem, Luong N. Nguyen, Felicity Roddick, and William E. Price
}




\title{
Removal of bisphenol A and diclofenac by a novel fungal membrane bioreactor operated under non-sterile conditions
}

\author{
Shufan Yang ${ }^{\text {a }}$, Faisal I. Hai ${ }^{\text {a, }}$, Long D. Nghiem ${ }^{\text {a }, \text { Luong N. Nguyen }}{ }^{\text {a }}$, Felicity Roddick ${ }^{\text {, }}$ \\ William E. Price ${ }^{\mathrm{c}}$
}

${ }^{a}$ Strategic Water Infrastructure Laboratory, School of Civil, Mining and Environmental Engineering, University of Wollongong, Wollongong, NSW 2500, Australia (E-mail: sy527@uowmail.edu.au; faisal@uow.edu.au; longn@uow.edu.au; lnn909@uowmail.edu.au)

${ }^{\mathrm{b}}$ School of Civil, Environmental and Chemical Engineering, RMIT University, Melbourne, Victoria 3001, Australia (E-mail: felicity.roddick@rmit.edu.au )

${ }^{\mathrm{c}}$ Strategic Water Infrastructure Laboratory, School of Chemistry, University of Wollongong, Wollongong, NSW 2500, Australia (E-mail: wprice@uow.edu.au)

* Corresponding author

Faisal I. Hai, Strategic Water Infrastructure Laboratory, School of Civil, Mining and Environmental Engineering, University of Wollongong, NSW 2500, Australia (E-mail: faisal@uow.edu.au, Phone : +61-2-4221-3054) 


\begin{abstract}
Previous studies have confirmed significant removal of various trace organic contaminants (TrOCs) by white-rot fungal cultures under sterile batch test conditions. However, little is known about TrOC removal in continuous flow fungal reactors in a non-sterile environment. This study reports the removal of two common TrOCs: bisphenol A and diclofenac, by a fungal membrane bioreactor (MBR). Sterile batch tests with "active" (biosorption and biodegradation) and "chemically inactivated" (biosorption only) Trametes versicolor (ATCC 7731) confirmed biodegradation as the main mechanism for the removal of both compounds. An MBR inoculated with $T$. versicolor was operated for a period of three months during which diclofenac and bisphenol A were continuously added to the synthetic wastewater. Relatively stable removal of bisphenol A (80-90\%) and diclofenac ( $55 \%)$ was achieved by applying a hydraulic retention time of two days, at the bisphenol A and diclofenac loadings of $475 \pm 25$ and $345 \pm 112 \mu \mathrm{g} / \mathrm{L} . \mathrm{d}$, respectively.
\end{abstract}

Keywords: white-rot fungi; membrane bioreactor; trace organic contaminants (TrOCs); biodegradation; extracellular enzymatic activity. 


\section{Introduction}

The widespread occurrence of trace organic contaminants (TrOCs) such as industrial chemicals, pharmaceuticals and personal care products in sewage-impacted water bodies has raised significant concerns due to their potential adverse effects on human health and aquatic ecology (Ternes et al., 2004). This necessitates the development of effective approaches to eliminating such compounds from wastewater. Due to the limitations of TrOC removal by the bacteriadominated conventional activated sludge (CAS) processes (Cirja et al., 2008), there have been a number of recent studies on the application of white-rot fungal bioremediation (see for example: Marco-Urrea et al. (2010) and Tran et al. (2010)). Evidence from the literature indicates that white-rot fungi can degrade various TrOCs, and the removal efficiency is governed by the physico-chemical properties of TrOCs, fungus strains and enzyme types (Marco-Urrea et al., 2010, Tran et al., 2010).

Despite the significant number of reports demonstrating the capacity of white-rot fungi to successfully degrade persistent TrOCs in small-scale sterile batch tests, far fewer studies have been conducted in continuous reactors (Blánquez and Guieysse, 2008, Jelic et al., 2012, RodarteMorales et al., 2012). Furthermore, only one study to date has investigated TrOC removal under non-sterile conditions as would likely be experienced in practice (Zhang and Geißen, 2012). Compared with the performance in pure culture batch tests, two inherent limitations have been reported to be the major reason for lower removal of persistent organic compounds such as dye by continuous flow fungal reactors: i) continuous washout of fungal extracellular enzyme with treated effluent (Zhang and $\mathrm{Yu}, 2000$, Hai et al., 2012b), and ii) bacterial destabilization of fungal activity (Libra et al., 2003, Gao et al., 2008, Hai et al., 2009). In good agreement with the studies concerning other groups of persistent compounds, recent studies on TrOC removal also report somewhat poorer removal by fungal reactors operated under non-sterile conditions and/or in continuous flow mode (Jelic et al., 2012, Rodarte-Morales et al., 2012, Zhang and Geißen, 2012). It is, therefore, clear that more systematic studies on the enhancement of fungal degradation of TrOCs in continuous reactors under non-sterile environments are necessary.

Membrane bioreactors (MBRs) represent an advancement over the CAS process, in that they combine biological degradation and membrane filtration in a single-step, compact process, and 
allow for flexibility in the application of different modifications to fine-tune biological performance (Hai and Yamamoto, 2011). The effectiveness of several modifications to MBR design for the fungal bioremediation of dye wastewater has been demonstrated recently (Hai et al., 2008, Hai et al., 2012b). However, to date no study has investigated TrOC removal by a fungal MBR.

The aim of this study was to investigate the TrOC removal performance of an MBR inoculated with a pure culture of the white-rot fungus Trametes versicolor (ATCC 7731) but subsequently operated without any planned measures to avoid bacterial growth. A series of sterile batch tests with "active" and "chemically inactivated" pure cultures of fungus and conventional bacteriadominated activated sludge, respectively were first conducted to demonstrate significantly better TrOC degradation capacity of the fungus strain used in this study. A fungal MBR was then operated for three months under non-sterile conditions to assess the TrOC removal performance in the presence of bacterial growth and at different TrOC loadings. A simple mass balance conducted at the end of operation allowed assessment of the relative contribution of biosorption and biodegradation to the overall TrOC removal.

\section{Materials and methods}

\subsection{Trace organic contaminants}

In this study, two TrOCs, namely, bisphenol A and diclofenac (Sigma-Aldrich, USA) were selected for batch tests and MBR operation. Key properties of these compounds are summarised in Table 1. Notably, diclofenac has been widely reported to be highly recalcitrant to bacterial degradation (Tadkaew et al., 2011, Nguyen et al., 2012), while bisphenol A has been reported to be comparatively easily removed by bacteria (Tadkaew et al., 2011, Nguyen et al., 2012). In order to be able to contrast the performance of the fungal MBR in this study with that of conventional MBRs reported in the literature, these two compounds were used as model TrOCs in the fungal MBR. They were prepared as stock solutions at a concentration of $1 \mathrm{~g} / \mathrm{L}$ in pure methanol, stored at $-18{ }^{\circ} \mathrm{C}$ and used within one month. 


\subsection{White-rot fungus, growth medium and synthetic wastewater}

The white-rot fungus Trametes versicolor ATCC 7731 was used in this study. Malt extract broth (MEB) was used for growth and the batch tests at concentrations of $10 \mathrm{~g} / \mathrm{L}$ and $0.25 \mathrm{~g} / \mathrm{L}$, respectively. A malt-based synthetic wastewater consisting of $\mathrm{MEB}(0.5 \mathrm{~g} / \mathrm{L}), \mathrm{KH}_{2} \mathrm{PO}_{4}(0.2 \mathrm{~g} / \mathrm{L})$, $\mathrm{MgSO}_{4}(0.05 \mathrm{~g} / \mathrm{L}), \mathrm{FeSO}_{4}(0.01 \mathrm{~g} / \mathrm{L})$ and thiamine $(0.001 \mathrm{~g} / \mathrm{L})$ was used for fungal MBR operation. All chemicals used for preparing the growth medium and the synthetic wastewater were dissolved in Milli-Q water. The $\mathrm{pH}$ value of both growth medium and synthetic wastewater was adjusted to 4.5 with $\mathrm{HCl}$. TrOCs were continuously added to the synthetic wastewater fed to the MBR at concentrations ranging from 300 to $1500 \mu \mathrm{g} / \mathrm{L}$ to assess the effect of TrOC loading.

\subsection{Batch test protocol}

Sterile test medium (100 mL) containing TrOCs (bisphenol A and diclofenac) at concentrations of $745 \pm 40 \mu \mathrm{g} / \mathrm{L}$ and $690 \pm 60 \mu \mathrm{g} / \mathrm{L}$, respectively, was mixed with approximately $0.2 \mathrm{~g} / \mathrm{L}$ pregrown fungus in $400 \mathrm{~mL}$ sterile beakers, covered with aluminium foil and incubated in a shaker at $70 \mathrm{rpm}$ and $30{ }^{\circ} \mathrm{C}$ for $168 \mathrm{~h}$. Supernatant samples for measuring TrOC concentrations and laccase activity were collected at $0,4,48,120$ and $168 \mathrm{~h}$. Separate cultures were incubated to assess the removal by chemically inactivated fungus (adsorption only) by adding sodium azide $(100 \mu \mathrm{M})$ to the test medium. If a fungus is capable of degrading TrOCs, the amount of TrOCs adsorbed onto live fungus mycelium can be expected to gradually decline over time. To capture the dynamics of TrOC biosorption by the fungal mycelium, an additional set of cultures with live fungus were incubated in the same fashion described above. After 48, 120 and $168 \mathrm{~h}$, the medium was decanted and the fungal biomass was harvested from these cultures. TrOC adsorbed on the biomass was extracted by a solvent extraction method (Wijekoon et al., 2013). All experiments were conducted in triplicate. The batch test with bacterial activated sludge was conducted maintaining similar conditions as described above. The protocol of source, culture and preparation of the activated sludge for the batch test has been detailed elsewhere (Yang et al., 2012).

\subsection{Fungal MBR set-up and operation protocol}

A laboratory scale glass reactor with a working volume of $5.5 \mathrm{~L}$ was used. The reactor was initially seeded with a pure culture of $T$. versicolor, however, no measures to avoid bacterial 
growth, such as sterilization of feed or filtration of supplied air, were taken. The initial fungus concentration in the reactor was approximately $3 \mathrm{~g} / \mathrm{L}$ (dry weight). Following inoculation, the culture was aerated for two days before the start of continuous operation. A hydrophilized PVDF hollow fiber membrane module (SADF0790M mini module, Mitsubishi Rayon Engineering, Japan) was submerged in the reactor. The membrane had a nominal pore size of $0.4 \mu \mathrm{m}$ with a total effective membrane surface area of $0.074 \mathrm{~m}^{2}$., The influent and effluent pumps were controlled by timers, operated on on/off cycles and flow rates depending on the desired hydraulic retention time (HRT): $5 \mathrm{~min}$ on $/ 5 \mathrm{~min}$ off ( $\mathrm{HRT}=1$ day, flow rate $=7.2 \mathrm{~mL} / \mathrm{min}$ ) or $3 \mathrm{~min}$ on $/ 7$ min off cycle $(H R T=2$ days, flow rate $=6.4 \mathrm{~mL} / \mathrm{min})$. This resulted in an average membrane flux of 1.54 LMH (HRT $=2$ days) or 3.08 LMH (HRT $=1$ day). A vacuum gauge (Model 840064, Sper Scientific Ltd. USA) which was connected to a data logging computer was used to monitor transmembrane pressure (TMP) as an indicator of membrane fouling. .

An aeration pump (ACO-002, Zhenjiang Sensen Industry Co. Ltd, China) supplied air into the reactor through a diffuser. Two peristaltic pumps (MasterFlex pump, Cole-Parmer, Australia) were used to supply influent and draw effluent. The MBR was placed in a water bath to maintain the mixed liquor at $26 \pm 2.8{ }^{\circ} \mathrm{C}$. The dissolved oxygen (DO) concentration in the reactor was monitored daily by a DO probe. Vigorous aeration was provided to avoid settling of the mixed liquor in the corners of the reactor, leading to a consistently high DO $(6.5 \pm 0.2 \mathrm{mg} / \mathrm{L})$. The mixed liquor $\mathrm{pH}$ was stable at $5.4 \pm 0.2$. Except for sampling, no biomass was withdrawn from the MBR.

\subsection{Analytical methods}

\subsubsection{Basic parameters and TrOC analysis}

All samples were kept at $4{ }^{\circ} \mathrm{C}$ and analysed within a week. Total organic carbon (TOC) and total nitrogen (TN) concentrations were measured simultaneously by a Shimadzu TOC/TN-V $\mathrm{V}_{\mathrm{CSH}}$ analyser (Japan). TOC analysis was conducted in non-purgeable organic carbon (NPOC) mode. MLSS and MLVSS determination followed standard methods (Eaton et al., 2005).

A HPLC system (Shimadzu, Kyoto, Japan), equipped with a Supelco Drug Discovery 300 x 4.6 $\mathrm{mm} \mathrm{C}-18$ column $(5 \mu \mathrm{m}$ pore size) and a UV-vis detector, was used to measure the TrOC 
concentrations. The detection wavelength was $280 \mathrm{~nm}$ and the column temperature was $20{ }^{\circ} \mathrm{C}$. The sample injection volume was $50 \mu \mathrm{L}$. The mobile phase comprised acetonitrile and Milli-Q water buffered with $25 \mathrm{mM} \mathrm{KH}_{2} \mathrm{PO}_{4}(\mathrm{pH}=4.8)$. Two eluents, $\mathrm{A}(80 \%$ acetonitrile $+20 \%$ buffer, $\mathrm{v} / \mathrm{v})$ and $\mathrm{B}(20 \%$ acetonitrile $+80 \%$ buffer, v/v) were delivered at $0.7 \mathrm{~mL} / \mathrm{min}$ through the column for $30 \mathrm{~min}$ in the following time-dependent gradient proportions: [Time (min), \% of B] = $[0,80],[12,80],[20,0],[25,0],[25,80]$. The limit of quantification for the analytes under investigation using these conditions was approximately $10 \mu \mathrm{g} / \mathrm{L}$.

\subsubsection{Enzymatic activity (laccase) analysis}

Under the conditions tested, the fungus exhibited extracellular secretion of the enzyme laccase. Laccase activity was measured by monitoring the change in absorbance at $468 \mathrm{~nm}$ due to the oxidation of 2,6-dimethoxy phenol (DMP) at room temperature over 2 min using a spectrophotometer (PharmaSpec UV-1700, Shimadzu, Kyoto, Japan). Laccase activity was calculated from the molar extinction coefficient $\varepsilon=49.6 / \mathrm{mM} / \mathrm{cm}$ and expressed in $\mu \mathrm{M}$ substrate/min.

To measure the biomass-bound enzymatic activity, $10 \mathrm{~mL}$ of MBR sludge was filtered (glass

fiber, $1 \mu \mathrm{m}$ ), washed with Milli-Q water and filtered again. The wet solid was then transferred to a $10 \mathrm{~mL}$ glass tube and mixed with $800 \mu \mathrm{L}$ of $10 \mathrm{mM}$ DMP solution and $1200 \mu \mathrm{L}$ of $100 \mathrm{mM}$ sodium citrate buffer solution $(\mathrm{pH}=4.5)$ by a vortex mixer (Ratek Instruments Pty Ltd, Australia) for 2 minutes. Methanol $(1000 \mu \mathrm{L})$ was added to the mixture to prevent further enzymatic reaction. The mixture was then centrifuged at $3750 \mathrm{x} g$ for 10 minutes and the absorbance of the supernatant was measured at $468 \mathrm{~nm}$. The wet solid was transferred to a clean, pre-weighed crucible and dried (Heath Lab Oven, Heatherton Laboratory Services Pty. Ltd, Australia) for 24 hours at $105^{\circ} \mathrm{C}$. The enzymatic activity of sludge was calculated as $\mu \mathrm{M} / \mathrm{min} / \mathrm{g}$ MLSS).

\subsubsection{Bacterial and fungal plate count}

Mixed liquor from the MBR system was centrifuged at $3750 \mathrm{x} g$ for 10 minutes and the resulting supernatant was used for monitoring viable fungal and bacterial count in the sample. The standard spread plate technique for fungal (Method 9610 C) and bacterial (Method 9215 C) 
detection was followed (Eaton et al., 2005). The agar plates used for fungal and bacterial detection were made from $50 \mathrm{~g} / \mathrm{L}$ malt extract agar (Oxoid, England) (pH adjusted to 3.5 with 10\% tartaric acid solution) and $22.5 \mathrm{~g} / \mathrm{L}$ bacterial plate count agar (Merck, Germany), respectively. The colonies of fungus and bacteria were counted after 72 and $48 \mathrm{~h}$ of incubation at $20{ }^{\circ} \mathrm{C}$, respectively, and the counts expressed as colony forming units $(\mathrm{CFU} / \mathrm{mL})$.

\section{Results and discussion}

\subsection{TrOC removal in batch tests}

Significant removal of both bisphenol A and diclofenac (62 and 60\%, respectively) from the aqueous phase by the live fungus occurred within $24 \mathrm{~h}$ of incubation (Figure 1a). Further gradual decrease in concentration occurred such that complete removal of bisphenol A and diclofenac was achieved in less than $120 \mathrm{~h}$. These results are consistent with those reported by Marco-Urrea et al. (2010) and Tran et al. (2010). In contrast, the reduction in the concentration of bisphenol A and diclofenac from the test solution incubated with inactivated fungus after $24 \mathrm{~h}$ was only 25 and $26 \%$, respectively, and no further significant removal was observed thereafter (Figure 1a). The presence of sodium azide completely stopped enzyme production (Figure 1c), meaning that the inactivated fungus removed the TrOCs solely by sorption. The comparative performance of the live and inactivated fungus confirmed biodegradation as the major mechanism in the overall removal of the compounds from the aqueous phase. Furthermore, extraction of residual adsorbed bisphenol A and diclofenac from live fungus at different times during the incubation period of up to $168 \mathrm{~h}$ confirmed that the biosorbed TrOCs continued to be gradually biodegraded (Figure $1 \mathrm{~b}$ ). The elucidation of the dynamics of TrOC sorption on live fungal mycelium is an important

additional outcome from our study. By contrast, the bacterial activated sludge achieved only about $20 \%$ and $15 \%$ degradation of bisphenol $\mathrm{A}$ and diclofenac within $24 \mathrm{~h}$, respectively, and no further degradation was observed within $120 \mathrm{~h}$ (data not shown).

\section{Figure 1}




\subsection{Operational stability and basic performance of the fungal MBR}

\subsubsection{Operational stability}

The key operating parameters such as $\mathrm{pH}$, temperature and DO concentration were stable throughout the operating period (Section 2.4). The MLSS concentration was $3 \pm 0.3 \mathrm{~g} / \mathrm{L}$ during the first 55 days, increased to $6.81 \mathrm{~g} / \mathrm{L}$ after addition of fresh fungus on day 55 (in an attempt to improve removal performance), and remained stable thereafter until the end of the experiment. The MLVSS/MLSS ratio remained constant at approximately 0.81 over the whole experimental period, indicating biological stability. Apart from two instances of ex-situ chemical cleaning of the membrane (submerged in $\mathrm{NaOCl}$ solution; active chlorine $=500 \mathrm{mg} / \mathrm{L}$ ) performed on day 5 and 23 due to moderate rise in TMP, no further membrane cleaning was required, and the TMP remained stable at $2 \mathrm{kPa}$ for the remainder of the study.

Fungal counts in the MBR supernatant samples (Figure 2) confirmed the presence of viable fungus in the MBR system throughout the experimental period. However, after an initial increase the colony number dropped by approximately $50 \%$ to $5.67 \times 10^{6} \mathrm{CFU} / \mathrm{mL}$ by the end of the experiment. As aseptic conditions were not maintained, bacteria were detected in the mixed liquor from the first day of continuous operation (Figure 2). The bacterial plate count was relatively stable at $(3.5 \pm 1.5) \times 10^{7} \mathrm{CFU} / \mathrm{mL}$ during the whole operation period. Fungi prefer to grow in pellet form in suspension. Thus, monitoring the fungal count in the mixed liquor supernatant sample may not accurately reflect the fungal concentration in the MBR. Nevertheless, our observation is in line with a prevalent idea in the literature that the presence of bacteria may disrupt fungal growth. More importantly, as noted above, monitoring the fungal count serves the important purpose of confirming presence of viable fungi in the MBR throughout the operating period.

\section{Figure 2}

\subsubsection{TOC and TN removal}

Over the three months of investigation under different TOC and TN concentrations in the feed, the MBR showed consistent performance with respect to removal of TOC $(81 \pm 13 \%)$ and TN $(84 \pm 3 \%)$ (Figure 3$)$. There was one instance of significant drop in TOC removal (to $45 \%)$ after 
day 25 as the TOC concentration in the feed was approximately doubled. The TOC removal, however, gradually returned to the initial level and remained stable thereafter until the end of the experiment (Figure 3). It is well known that the TOC consumption rate of pure fungal cultures from solutions containing easily degradable organics is limited compared to bacteria (Hai et al., 2012a). However, because the MBR was operated under non-sterile conditions, bacterial presence was evident from viable bacterial counts in mixed liquor supernatant (Figure 2), and the growth of bacteria in the reactor can explain the achievement of over $80 \%$ TOC removal in this study. This observation is consistent with that in a few other studies (Hai et al., 2008, Hai et al., 2009). On the other hand, the denitrification capacity of an aerobic MBR system is limited. However, the malt-based synthetic wastewater used in this study had a high TOC/TN ratio ( 40) which can be considered as nitrogen limited medium. The high TN removal, therefore, could be ascribed to the conversion of dissolved organic nitrogen to biomass (Hai et al., 2011).

\section{Figure 3}

\subsection{TrOC removal by fungal MBR}

TOC removal is important from the point of view of a complete treatment of the mixed wastewater. However, the extent of TOC consumption cannot be taken as an indicator of TrOC degradation as the TOC was mostly supplied by malt. Therefore, the removal of each of the TrOC has been monitored to assess the effect of TrOC loading. Figure 4 shows the TrOC loadings in feed and corresponding removal efficiency and the laccase activity of the supernatant, permeate and sludge throughout the operation period.

\section{Figure 4}

\subsubsection{Effect of TrOC loading}

High removal ( $\sim 80 \%)$ of diclofenac and bisphenol A was recorded initially (Figure 4a). Bisphenol A removal improved further and almost complete removal was observed for three weeks. Diclofenac removal, on the other hand, gradually dropped from 80 to $40 \%$ over the same time. Further reduced removal of both TrOCs was observed under increased TrOC loading applied during day 25 to 70. Of particular interest was the improvement of the removal performance of the TrOCs from day 71 (Figure 4a) as the TrOC loadings were reduced to 475.5 
$\pm 25 \mu \mathrm{g} / \mathrm{L}$ (bisphenol A) and $345 \pm 112 \mu \mathrm{g} / \mathrm{L}$ (diclofenac). Apparently, the loading applied until day 70 exceeded the biodegradation capacity of this fungal MBR system. Indeed a further increase in bisphenol A (>90\%) removal and a consistent removal of diclofenac ( $55 \%)$, respectively, were obtained following a further ca. 50\% reduction in the TrOC loadings (to $234 \pm$ $35.5 \mu \mathrm{g} / \mathrm{L}$ and $171 \pm 12.5 \mu \mathrm{g} / \mathrm{L}$ for bisphenol A and diclofenac, respectively).

Periodic fresh fungus addition has been shown to be beneficial in sustaining performance of continuous fungal reactors (Blánquez et al., 2008, Hai et al., 2012b). However, the removal of both bisphenol A and diclofenac suddenly decreased after the addition of fresh fungus on day 55 . The reason for this unexpected observation could not be ascertained, and further detailed investigation in this line is underway in our laboratory.

\subsubsection{Comparison of results from batch test and MBR operation}

The observed removal of the investigated compounds by the MBR under the applied loading is remarkable (Figure 4), particularly for diclofenac which has been widely reported to be poorly removed in conventional bacteria-dominated MBRs (Clara et al., 2005, Cirja et al., 2008, Tadkaew et al., 2011). However, compared with the performance of the pure fungus culture in batch tests, diclofenac removal was low in the continuous MBR. Based on the significantly better fungal degradation of TrOC over bacterial degradation in batch tests (Section 3.1), fungi can be logically expected to be mainly responsible for TrOC biodegradation in an MBR harbouring both bacteria and fungi. Therefore the reduced performance of the MBR in this study can be explained by two factors affecting fungal degradation in a continuous flow reactor: i) the continuous loss of enzyme along with treated effluent (Hai et al., 2009, Hai et al., 2012b) and, ii) inhibition of fungal degradation capacity due to competition with bacteria for TOC, bacterial damage of fungal mycelium and bacterial denaturation of fungal enzyme (Heinfling et al., 1998, Libra et al., 2003, Hai et al., 2009), as discussed further in section 3.3.3. An additional reason contributing to the lower removal of diclofenac by the MBR may be less adsorption of diclofenac to the biomass from the mixed liquor and, consequently, insufficient retention time to complete biodegradation. The $\mathrm{pH}$ of the mixed liquor in the MBR $(\mathrm{pH}=5.4)$ was higher than that of the batch test medium $(\mathrm{pH}=4.5)$. Diclofenac, unlike bisphenol $\mathrm{A}$, is a charged compound, and has a lower log $\mathrm{D}$ value 
at higher $\mathrm{pH}(\log \mathrm{D}$ values of 4.33 and 3.66 at a $\mathrm{pH}$ of 4 and 6 , respectively), which may have led to its lower biosorption to the biomass in the MBR.

Our observation of lower removal of the persistent compound diclofenac in the MBR is in good agreement with those in recent studies on fungal reactors operated under non-sterile conditions and/or in continuous flow mode (Jelic et al., 2012, Rodarte-Morales et al., 2012, Zhang and Geißen, 2012). Rodarte-Morales et al. (2012) reported decreased removal of anti-inflammatory drugs due to change in the operation mode of a fungal reactor from fed-batch to continuous flow. By applying an HRT of 3 days, Jelic et al. (2012) obtained up to 54\% removal of carbamazepine by a fluidized bed bioreactor. Zhang et al. (2012) reported a $60 \%$ removal of carbamazepine by an attached growth (on porous polyether foam) fungal reactor treating non-sterile real sewage treatment plant effluent.

\subsubsection{Enzymatic activity and TrOC removal}

No clear relationship between laccase activity and TrOC removal throughout the experimental period could be observed (Figure 4b). In fact laccase activity was detected in MBR-permeate from the start of operation, confirming passage of enzyme through the microfiltration membrane, and within six days of initiation of continuous operation, the laccase activity in both supernatant and permeate dropped to an undetectable level (Figure 4b). Apart from the continuous loss of enzyme in permeate, inhibition of the fungal enzyme system by the bacteria may be responsible for the marked reduction in the fungal enzymatic activity (Heinfling et al., 1998, Libra et al., 2003, Gao et al., 2008). Bacterial competition is reported to lead to cessation of fungal growth and inhibition of fungal enzyme secretion capacity or denaturation of the secreted fungal enzyme (Heinfling et al., 1998, Libra et al., 2003). Disappearance or very low level of extracellular enzymatic activity (compared with pure culture) has been also reported in other studies investigating continuous fungal reactors (Gao et al., 2008, Hai et al., 2012b, Zhang and Geißen, 2012). Nevertheless, it should be noted that, unlike the mixed liquor supernatant, biomassassociated laccase activity was always detectable in the MBR (Figure 4b)

Previous studies have shown that while enzyme is indispensable for the degradation of recalcitrant compounds, extracellular and mycelium-associated enzymatic activities do not necessarily correlate well with the removal efficiency (Hai et al., 2009, Hai et al., 2012b). 
Furthermore, intracellular enzymes, such as the cytochrome P450 enzyme system of fungus, are also reported to be helpful for TrOCs removal (Golan-Rozen et al., 2011), especially, in the context of this study, for diclofenac (Hata et al., 2010).

\subsubsection{Extent of TrOC biodegradation within MBR}

At the end of MBR operation, residual amounts of bisphenol A and diclofenac on sludge samples were measured after extraction, and a simple mass balance calculation was conducted. Over the whole operation period, approximately $290 \mathrm{mg}$ bisphenol A and $280 \mathrm{mg}$ diclofenac were fed into the MBR. Due to incomplete removal, $120 \mathrm{mg}$ bisphenol A and $180 \mathrm{mg}$ diclofenac escaped in the permeate, meaning that approximately $170 \mathrm{mg}$ bisphenol $\mathrm{A}$ and $100 \mathrm{mg}$ diclofenac were retained (biodegraded/biosorbed) within the MBR. The amount of sludge withdrawal through MLSS/MLVSS sampling was minimal, and the residual amount of bisphenol A and diclofenac on sludge at the end of operation were only ca. $2.75 \mathrm{mg}$ and $4.67 \mathrm{mg}$ ( 75 and $125 \mu \mathrm{g} / \mathrm{g}$ MLSS), respectively. Given the very low vapour pressure or Henry's constant $(\mathrm{H})$ and low $\mathrm{H} / \log \mathrm{D}$ ratio of the TrOCs selected in this study (Table 1), their removal by volatilization is expected to be negligible. Inefficient bacterial TrOC degradation (particularly of diclofenac) is evident from our batch test data and that from the available conventional MBR studies (Clara et al., 2005, Cirja et al., 2008, Tadkaew et al., 2011). Thus fungal degradation appeared to be a major mechanism of TrOC removal by the MBR in this study. This observation is in line with our own batch test data showing excellent TrOC degradation by pure fungus culture (Figure 1) and also with that in recent literature on removal of TrOCs by continuous fungal reactors (Blánquez and Guieysse, 2008, Jelic et al., 2012).

\section{Conclusion}

In this study, whole-cell preparations of Trametes versicolor achieved complete removal of bisphenol $\mathrm{A}$ and diclofenac in sterile batch tests where biodegradation governed the overall performance. The performance of a continuous flow fungal MBR was dependent on TrOC loading. At an HRT of two days and TrOC loadings of $475 \pm 25$ (bisphenol A) and $345 \pm 112$ (diclofenac) $\mu \mathrm{g} / \mathrm{L} . \mathrm{d}, 80-90 \%$ removal of bisphenol $\mathrm{A}$ and approximately $55 \%$ removal of diclofenac were achieved. Compared with the performance in pure fungal batch tests, the presence of bacteria in the MBR led to the following two distinct observations: (i) higher 
removal of TOC which was mainly composed of easily biodegradable malt, and (ii) reduced removal of diclofenac. Nevertheless, a simple mass balance conducted at the end of operation revealed that a major portion of bisphenol $\mathrm{A}$ and diclofenac adsorbed onto MBR-sludge had undergone biodegradation.

\section{Acknowledgement}

Dr. Faisal I. Hai acknowledges a grant from the University Research Committee of University of Wollongong, Australia to carry out this work.

\section{References}

Blánquez, P. \& Guieysse, B. 2008. Continuous biodegradation of $17 \beta$-estradiol and $17 \alpha-$ ethynylestradiol by Trametes versicolor. Journal of Hazardous Materials, 150, 459-462.

Blánquez, P., Sarrà, M. \& Vicent, T. 2008. Development of a continuous process to adapt the textile wastewater treatment by fungi to industrial conditions. Process Biochemistry, 43, $1-7$.

Cirja, M., Ivashechkin, P., Schäffer, A. \& Corvini, P. F. X. 2008. Factors affecting the removal of organic micropollutants from wastewater in conventional treatment plants (CTP) and membrane bioreactors (MBR). Reviews in Environmental Science \& Biotechnology, 7, $61-78$

Clara, M., Strenn, B., Gans, O., Martinez, E., Kreuzinger, N. \& Kroiss, H. 2005. Removal of selected pharmaceuticals, fragrances and endocrine disrupting compounds in a membrane bioreactor and conventional wastewater treatment plants. Water Research, 39, 4797 4807.

Eaton, A. D., Association, A. P. H., Federation, W. E. \& Association, A. W. W. 2005. Standard methods for the examination of water and wastewater, Washington, D. C.

Gao, D., Zeng, Y., Wen, X. \& Qian, Y. 2008. Competition strategies for the incubation of white rot fungi under non-sterile conditions. Process Biochemistry, 43, 937-944.

Golan-Rozen, N., Chefetz, B., Ben-Ari, J., Geva, J. \& Hadar, Y. 2011. Transformation of the recalcitrant pharmaceutical compound carbamazepine by Pleurotus ostreatus: role of cytochrome P450 monooxygenase and manganese peroxidase. Environmental Science \& Technology, 45, 6800-6805. 
Hai, F. I., Yamamoto, K., Nakajima, F. \& Fukushi, K. 2008. Removal of structurally different dyes in submerged membrane fungi reactor-Biosorption/PAC-adsorption, membrane retention and biodegradation. Journal of Membrane Science, 325, 395-403.

Hai, F. I., Yamamoto, K., Nakajima, F. \& Fukushi, K. 2009. Factors governing performance of continuous fungal reactor during non-sterile operation - The case of a membrane bioreactor treating textile wastewater. Chemosphere, 74, 810-817.

Hai, F. I., Tessmer, K., Nguyen, L. N., Kang, J., Price, W. E. \& Nghiem, L. D. 2011. Removal of micropollutants by membrane bioreactor under temperature variation. Journal of Membrane Science, 383, 144-151.

Hai, F. I. \& Yamamoto, K. 2011. 4.16 - Membrane Biological Reactors. In: Peter, W. (ed.) Treatise on Water Science. Oxford: Elsevier.

Hai, F. I., Modin, O., Yamamoto, K., Fukushi, K., Nakajima, F. \& Nghiem, L. D. 2012 a. Pesticide removal by a mixed culture of bacteria and white-rot fungi. Journal of the Taiwan Institute of Chemical Engineers, 43, 459-462.

Hai, F. I., Yamamoto, K., Nakajima, F. \& Fukushi, K. 2012b. Application of a GAC-coated hollow fiber module to couple enzymatic degradation of dye on membrane to whole cell biodegradation within a membrane bioreactor. Journal of Membrane Science, 389, 67-75.

Hata, T., Kawai, S., Okamura, H. \& Nishida, T. 2010. Removal of diclofenac and mefenamic acid by the white rot fungus Phanerochaete sordida YK-624 and identification of their metabolites after fungal transformation. Biodegradation, 21, 681-9.

Heinfling, A., Martínez, M. J., Martínez, A. T., Bergbauer, M. \& Szewzyk, U. 1998. Transformation of industrial dyes by manganese peroxidases from Bjerkandera adusta and Pleurotus eryngii in a manganese-independent reaction. Applied and Environmental Microbiology, 64, 2788-2793.

Jelic, A., Cruz-Morató, C., Marco-Urrea, E., Sarrà, M., Perez, S., Vicent, T., Petrović, M. \& Barcelo, D. 2012. Degradation of carbamazepine by Trametes versicolor in an air pulsed fluidized bed bioreactor and identification of intermediates. Water Research, 46, 955-964.

Libra, J. A., Borchert, M. \& Banit, S. 2003. Competition strategies for the decolorization of a textile-reactive dye with the white-rot fungi Trametes versicolor under non-sterile conditions. Biotechnology and Bioengineering, 82, 736-744. 
Marco-Urrea, E., Pérez-Trujillo, M., Cruz-Morató, C., Caminal, G. \& Vicent, T. 2010.

Degradation of the drug sodium diclofenac by Trametes versicolor pellets and identification of some intermediates by NMR. Journal of Hazardous Materials, 176, 836842.

Nguyen, L. N., Hai, F. I., Kang, J., Price, W. E. \& Nghiem, L. D. 2012. Removal of trace organic contaminants by a membrane bioreactor-granular activated carbon (MBR-GAC) system. Bioresource Technology, 113, 169-173.

Rodarte-Morales, A. I., Feijoo, G., M.Teresa, M. \& Lema, J. 2012. Evaluation of two operational regimes fed-batch and continuous for the removal of pharmaceuticals in a fungal stirred tank reactor. Chemical engineering transactions, 27, 151-156.

Tadkaew, N., Hai, F. I., McDonald, J. A., Khan, S. J. \& Nghiem, L. D. 2011. Removal of trace organics by MBR treatment: The role of molecular properties. Water Research, 45, 24392451.

Ternes, T. A., Joss, A. \& Siegrist, H. 2004. Peer Reviewed: Scrutinizing Pharmaceuticals and Personal Care Products in Wastewater Treatment. Environmental Science \& Technology, 38, 392A-399A.

Tran, N. H., Urase, T. \& Kusakabe, O. 2010. Biodegradation characteristics of pharmaceutical substances by whole fungal culture Trametes versicolor and its laccase. Journal of Water and Environment Technology, 8, 125-140.

Wijekoon, K., Fujioka, T., McDonald, J., Khan, S. J., Hai, F. I., Price, W. E. \& Nghiem, L. D. 2013. Removal of N-nitrosamines by an aerobic membrane bioreactor. Bioresource Technology, (accepted, Jan. 2013).

Yang, S., Hai, F. I., Nghiem, L. D., Roddick, F. \& Price, W. E. 2012. Removal of trace organic contaminants by nitrifying activated sludge and whole-cell and crude enzyme extract of Trametes versicolour. Water Science and Technology, (accepted, Nov. 2012).

Zhang, F. \& Yu, J. 2000. Decolourisation of Acid Violet 7 with complex pellets of white rot fungus and activated carbon. Bioprocess Engineering, 23, 295-301.

Zhang, Y. \& Geißen, S.-U. 2012. Elimination of carbamazepine in a non-sterile fungal bioreactor. Bioresource Technology, 112, 221-227. 


\section{List of Figures}

Figure 1 (a) Removal of bisphenol A and diclofenac from aqueous phase, (b) mass of bisphenol A and diclofenac adsorbed on the mycelium of live fungus, and (c) the laccase activity of culture supernatant, during incubation of live and inactivated fungi in $0.25 \mathrm{~g} / \mathrm{L}$ malt extract broth. The initial $\mathrm{pH}$ and fungus concentration were 4.5 and $0.2 \mathrm{~g} / \mathrm{L}$, respectively. The initial concentrations of BPA and DCF were $745 \pm 40 \mu \mathrm{g} / \mathrm{L}$ and $690 \pm 60 \mu \mathrm{g} / \mathrm{L}$, respectively. Error bar represents the standard deviation $(\mathrm{n}=3)$.

Figure 2 Viable fungal and bacterial count in MBR-supernatant. Error bar represents the standard deviation $(\mathrm{n}=3)$.

Figure $3 \mathrm{TOC}$ and TN removal throughout the operation period. As indicated on the figure, the concentrations of TOC and TN in the feed as well as the HRT were maintained at different levels over different stages of operation.

Figure 4 (a) TrOC loading and removal efficiency, and (b) the change in laccase activity of the supernatant, permeate and sludge throughout the operating period. Similar loading under longer HRT corresponds to higher concentrations of TrOCs in the feed. 

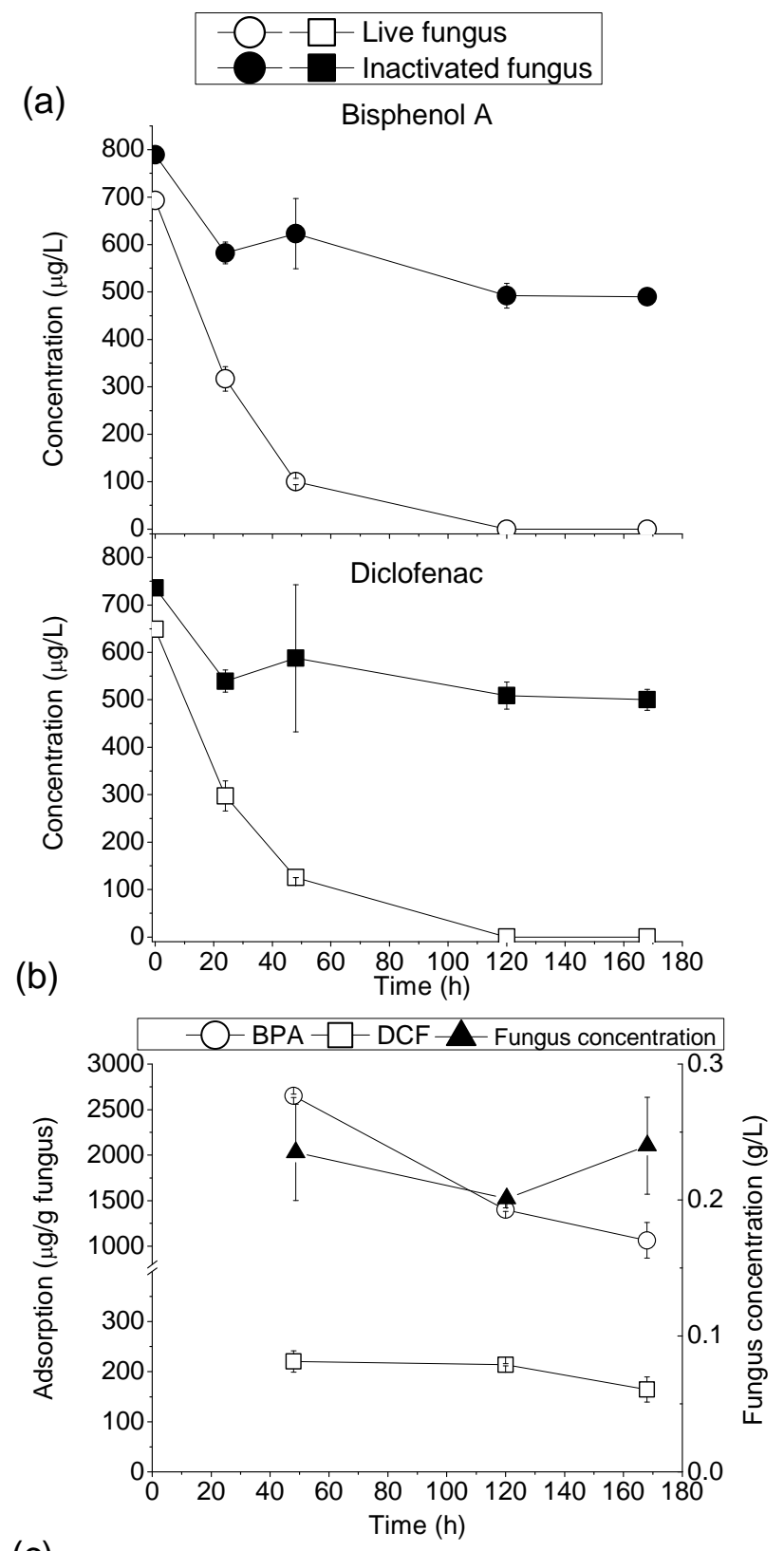

(c)

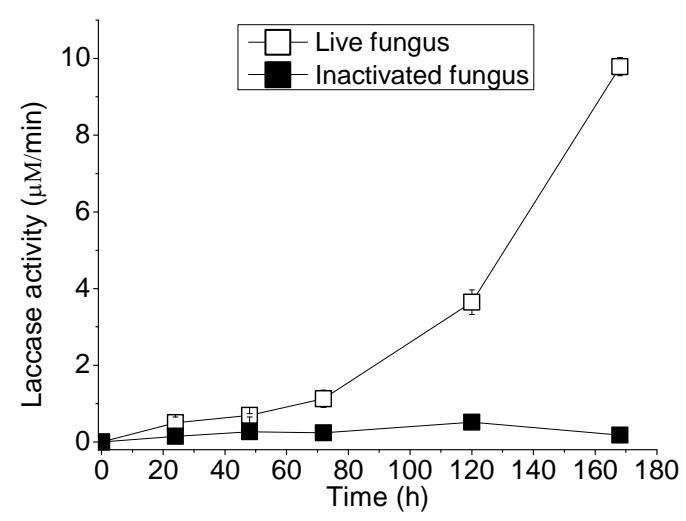




\section{Figure 1}

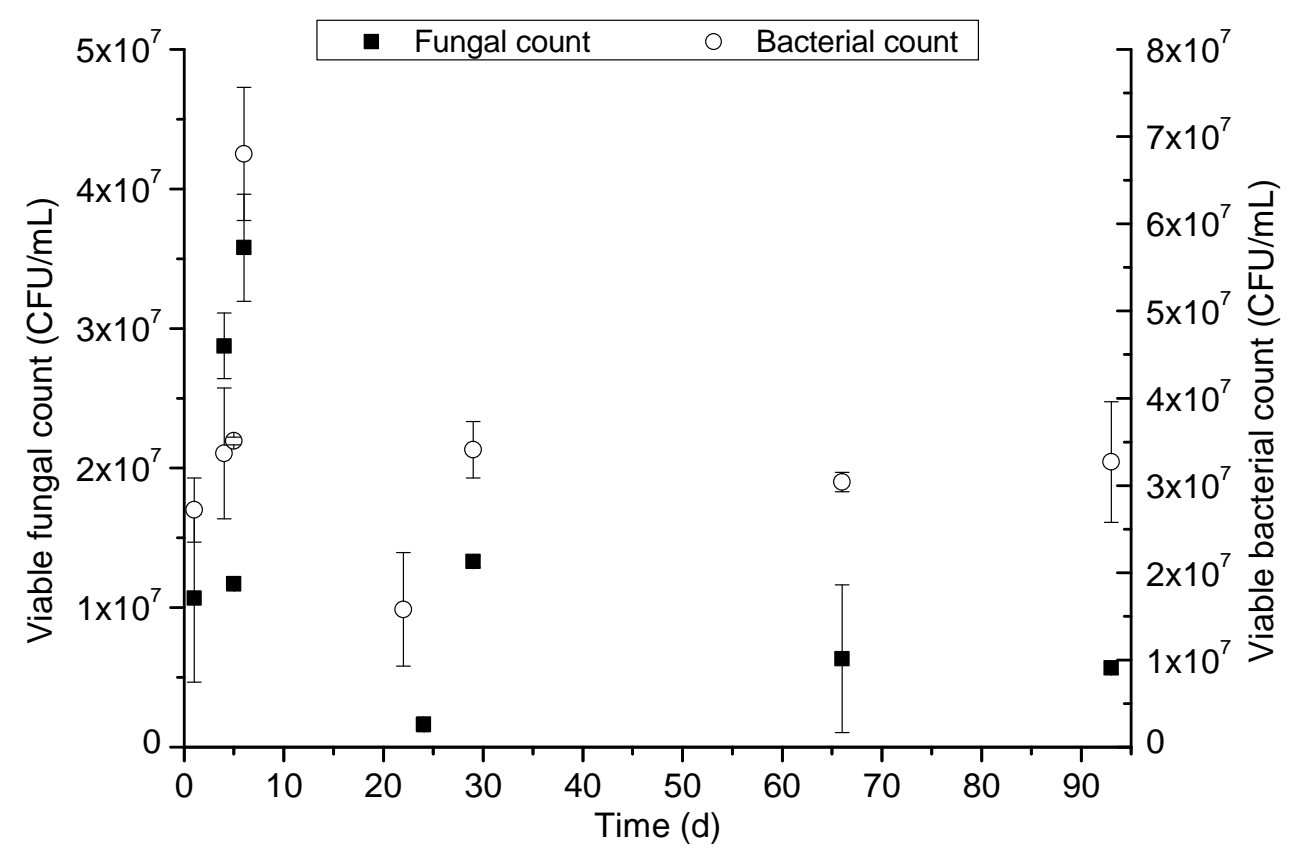

Figure 2 


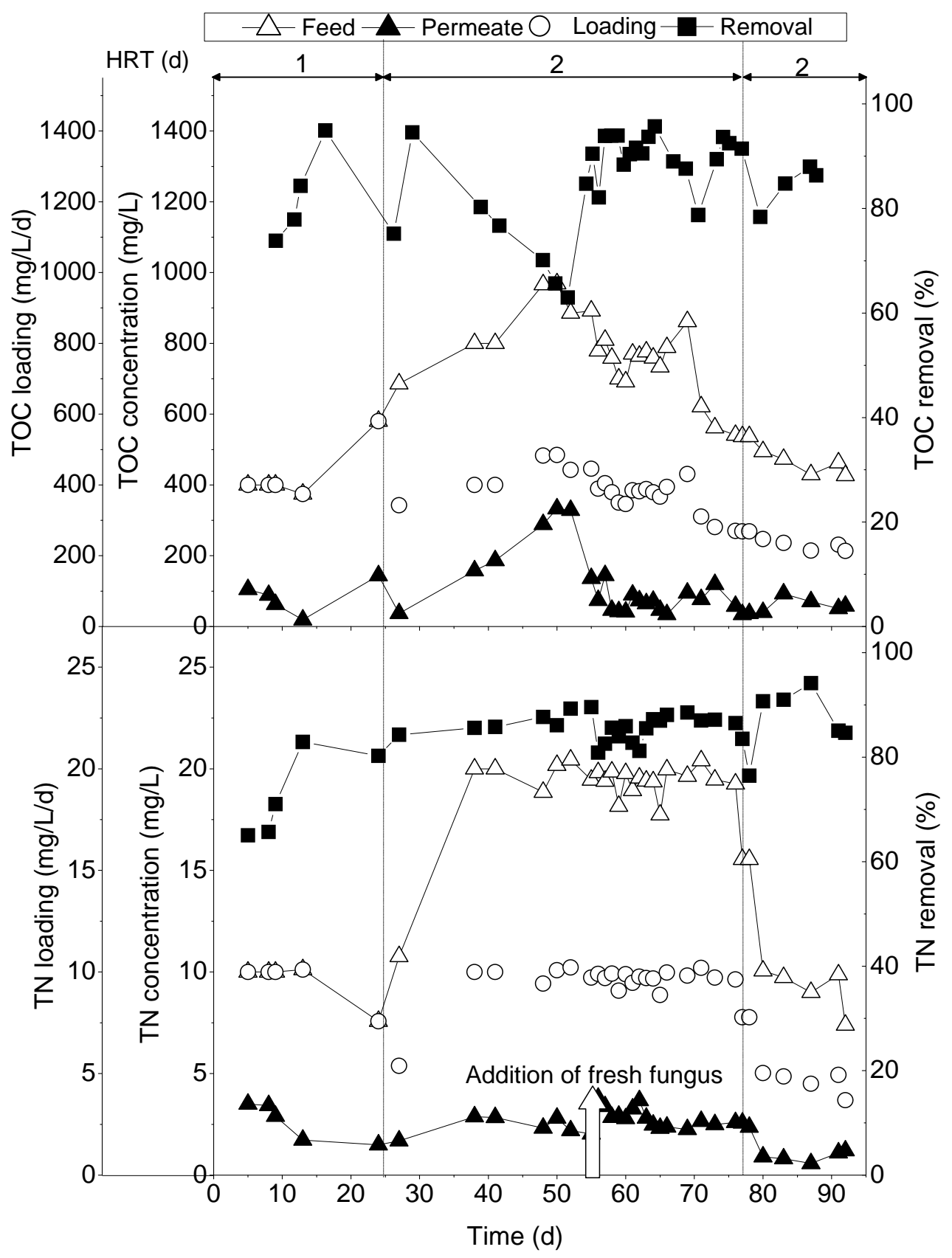

Figure 3 


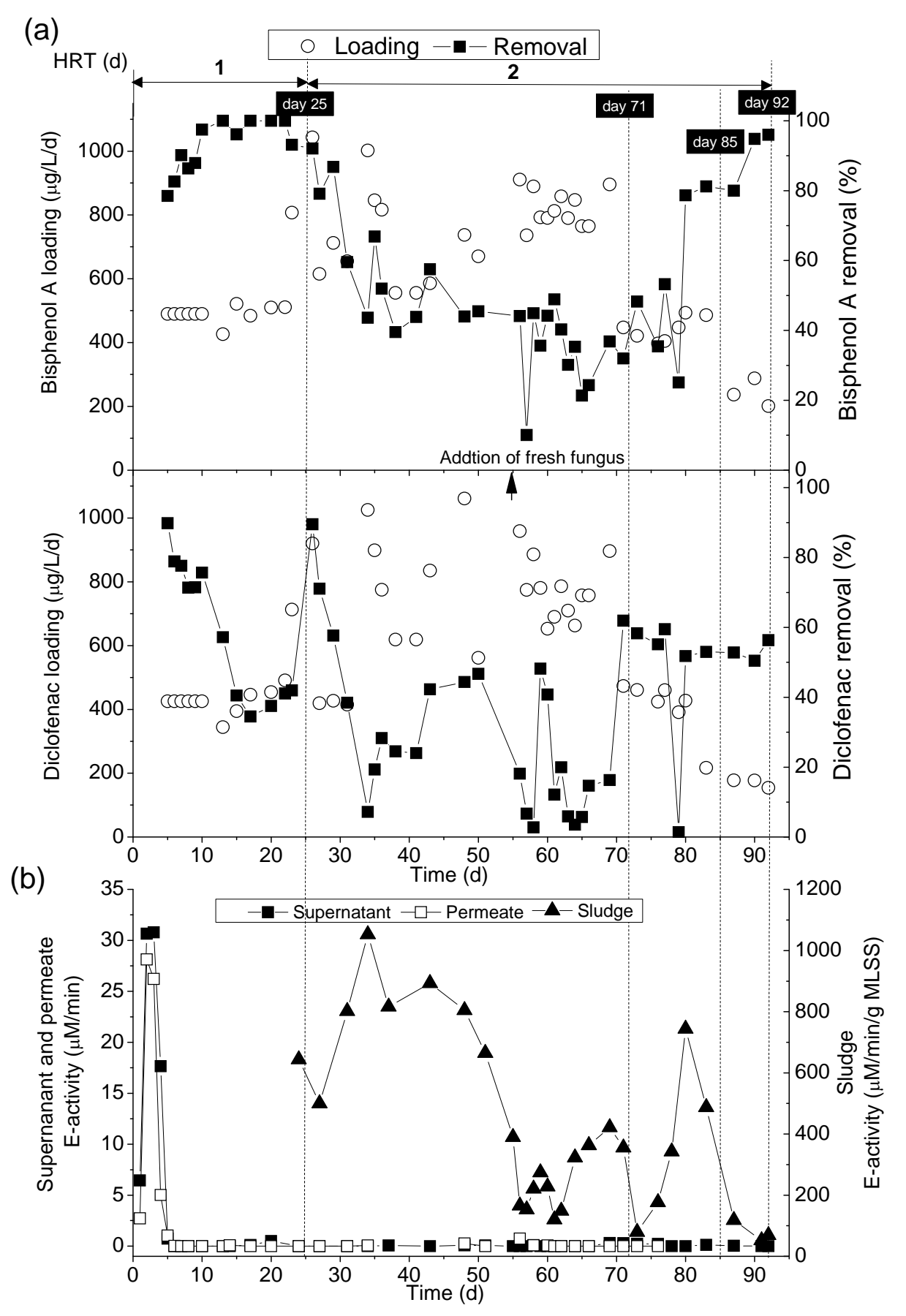

Figure 4 
Table 1 Physicochemical properties of the selected trace organic contaminants.

\begin{tabular}{ccccccc}
\hline Category & Compound & $\begin{array}{c}\mathrm{Log} \mathrm{D} \\
(\mathrm{pH}=4)^{\mathrm{a}}\end{array}$ & $\begin{array}{c}\mathrm{Log} \mathrm{D} \\
(\mathrm{pH}=7)^{\mathrm{a}}\end{array}$ & $\begin{array}{c}\text { Dissociation } \\
\text { constant } \\
(\mathrm{pKa})^{\mathrm{a}}\end{array}$ & $\begin{array}{c}\text { Water } \\
\text { solubility } \\
(\mathrm{mg} / \mathrm{L})^{\mathrm{b}}\end{array}$ & $\begin{array}{c}\text { Vapor } \\
\text { pressure } \\
(\mathrm{mm} \\
\mathrm{Hg}), \text { at } \\
25^{\circ} \mathrm{C}^{\mathrm{a}}\end{array}$ \\
\hline Pharmaceutical & $\begin{array}{c}\text { Diclofenac } \\
\left(\mathrm{C}_{14} \mathrm{H}_{11} \mathrm{Cl}_{2} \mathrm{NO}_{2}\right)\end{array}$ & 4.33 & 1.77 & $4.18 \pm 0.10$ & 2.37 & $1.59 \mathrm{E}-7$ \\
\hline $\begin{array}{c}\text { Endocrine } \\
\text { disrupting } \\
\text { chemical }\end{array}$ & $\begin{array}{c}\mathrm{Bisphenol} \mathrm{A} \\
\left(\mathrm{C}_{15} \mathrm{H}_{16} \mathrm{O}_{2}\right)\end{array}$ & 3.64 & 3.64 & $10.29 \pm 0.10$ & 120 & \\
\hline
\end{tabular}

${ }^{a}$ Source: SciFinder database https://scifinder.cas.org/scifinder/view/scifinder/scifinderExplore.jsf

${ }^{\mathrm{b}}$ Source: http://chem.sis.nlm.nih.gov/chemidplus/ 